\title{
Hypercapnia as the Only Early Sign of Pneumothorax in Patient under General Anaesthesia
}

\author{
Genel Anestezi Altındaki Hastada Pnömotoraksın Tek Erken Belirtisi Olarak Hiperkapni
}

Lin Jett Hau ${ }^{1}$, Ahmad Rusmili Hasyimah Siti ${ }^{1}$, Palamong Binti Nurhafizah ${ }^{1}$, Mat Sani Fauzy Mohd ${ }^{1}$, Han Yeh Poh ${ }^{1}$

Tat Boon Yeap ${ }^{2}$

${ }^{1}$ Department of Anaesthesiology and Intensive Care, Hospital Lahad Datu, Sabah, Malaysia

${ }^{2}$ Department of Medicine, Faculty of Medicine and Health Sciences, Universiti Malaysia Sabah, Kota Kinabalu, Sabah, Malaysia

\section{ABSTRACT}

Pneumothorax is a well-known but rare complication of general anaesthesia (GA). Its presentation can be subtle and difficult to diagnose especially under GA. We present a case of a 50-year-old man who is a chronic smoker, underwent an emergency exploratory laparotomy for perforated gastric ulcer. After induction, there was hypercapnia which progressively worsened. Common causes of hypercapnia were excluded. Unequal breath sounds and tracheal deviation presented late and there was never desaturation. Bedside lung ultrasound showed absence of sliding sign and presence of bar-code sign over right lung which suggested right pneumothorax. Needle thoracocentesis and chest tube insertion were done upon diagnosis. We recommend that pneumothorax be suspected early in patient with persistent unexplained hypercapnia under GA and anaesthesiologists to be able to perform lung ultrasound as early intervention could be life saving.

Key Words: Hypercapnia, pneumothorax, general anaesthesia

Received: 10.07 .2018

Accepted: 12.05 .2018

\section{ÖZET}

Pnömotoraks, genel anestezinin (GA) iyi bilinen fakat nadir görülen bir komplikasyonudur. Sunumu özellikle GA altında, ince ve teşhis edilmesi zor olabilir. Kronik sigara içen 50 yaşında bir erkek olguda perfore gastrik ülser nedeniyle acil eksplorasyon laparotomisi yapıldı. Indüksiyondan sonra, progresif olarak kötüleşen hiperkapni vardı. Hiperkapninin ortak nedenleri dışlandı. Eşit olmayan nefes sesleri ve trakeal sapma geç ortaya çıktı ve asla desatürasyon olmadı. Bedside akciğer ultrasonu, sağ pnömotoraks için önerilen akciğer kaymasının olmadığını ve sağ akciğer üzerinde barkod işaretinin bulunduğunu gösterdi. Torakosentez ve göğüs tüpünün yerleştirilmesi tanı sonrası konuldu. GA altında persistan açıklanamayan hiperkapnisi olan hastalarda pnömotorakstan şüphelenilmesini ve erken müdahale hayat kurtarıcı olabileceğinden, anestezi uzmanlarının akciğer ultrasonu yapmalarını öneririz.

Anahtar Sözcükler: Hiperkapni, pnömotoraks, genel anestezi

Geliş Tarihi: 07.10.2018

Kabul Tarihi: 05.12.2018

\section{INTRODUCTION}

Pneumothorax is an established but rare complication of GA. Classically, patient presents with shortness of breath, chest pain, reduced chest expansion, hyper-resonant percussion notes and reduced breath sounds over affected side associated with hypoxia. In tension pneumothorax, there may be tracheal deviation to the opposite side. Nevertheless, presentation of pneumothorax can be subtle and difficult to diagnose especially in patients under GA.

We present a case of an unusual presentation of pneumothorax that happened to a patient under $\mathrm{GA}$.

\section{CASE REPORT}

A 50-year-old gentleman presented with gradual onset of epigastric pain for three days which later became generalized and associated with nausea, vomiting and no bowel output for one day. On examination, his abdomen was distended, tense and guarded with generalized tenderness. Erect chest X-ray showed air under diaphragm and otherwise clear lung fields. He was posted for emergency laparotomy for perforated gastric ulcer under GA. Pre-morbidly, he was a chronic smoker with frequent difficulty in breathing without proper follow-up.

Address for Correspondence / Yazışma Adresi: Boon Tat Yeap, MD Department of Medicine, Faculty of Medicine and Health Sciences, Universiti Malaysia Sabah, Kota Kinabalu, Sabah, Malaysia E-mail: boontat@ums.edu.my

CTelif Hakkı 2019 Gazi Üniversitesi Tıp Fakültesi - Makale metnine http://medicaljournal.gazi.edu.tr/ web adresinden ulaşılabilir.

(C) Copyright 2019 by Gazi University Medical Faculty - Available on-line at web site http://medicaljournal.gazi.edu.tr/

doi:http://dx.doi.org/10.12996/gmj.2019.53 
Induction of anaesthesia was uneventful and he was intubated with a cuffed endotracheal tube (ETT) size $7.5 \mathrm{~mm}$ anchored at $22 \mathrm{~cm}$. Air entry was equal bilaterally post-intubation. Initial ventilator setting was minute ventilation $5 \mathrm{~L} / \mathrm{min}$ (tidal volume $\sim 330 \mathrm{~mL}$ ), rate $15 / \mathrm{min}$ and Inspiration:Expiration ratio of 1:2 with Fraction of inspired oxygen of 1.0 (estimated weight $55 \mathrm{~kg}$, nitrous oxide was not used in view of pneumoperitoneum and there was no "Air" option for this ventilator). Anaesthesia was maintained with Sevoflurane to achieve MAC of 0.91.0 .

However, 15 minutes post-induction it was noted that end-tidal carbon dioxide (etCO2) level was high (44-46 $\mathrm{cmH} 2 \mathrm{O}$ ) and progressively increased (52-58 $\mathrm{cmH2O}$ ) even after abdominal cavity was opened by surgeon. Repeated auscultations showed equal air entry bilaterally with no adventitious sound.

Corrective measures were taken including increased set respiratory rate at $25 / \mathrm{min}$, I:E ratio $1: 3$, increased minute ventilation to achieve tidal volume $\sim 450 \mathrm{~mL}$, manual hyperventilation and re-anchoring of ETT at $21 \mathrm{~cm}$ with the thought of possible endobronchial migration of tube. There was no increased resistance noted during hand ventilation. Trial of metered-dose inhaler salbutamol was also given but no improvement was seen. Besides, kinking and mucous plus obstruction of ETT were ruled out and circuit were checked to ensure no leaking. Minimum alveolar concentration (MAC) was kept at 0.9-1.0 to prevent hypercapnia due to light anaesthesia. Oxygen saturation maintained $100 \%$ throughout event and patient remained normothermia.

Nevertheless, etCO2 level persistently increased to highest at $92 \mathrm{cmH} 2 \mathrm{O} 1.5$ hour after induction. By then, auscultation of lungs revealed generalized reduced air entry over right lung. There was no rhonchi or prolonged expiratory phase and peak inspiratory pressure (PIP) remained around $18 \mathrm{cmH} 2 \mathrm{O}$. Chest expansion was also reduced over right lung with trachea deviation to left. However, there was no hyper-resonance on percussion.

Haemodynamically, he was hypotensive with systolic blood pressure (SBP) ranging $70-100 \mathrm{mmHg}$ and diastolic blood pressure (DBP) of $42-64 \mathrm{mmHg}$ with tachycardia despite vigorous fluid infusion and vasopressors. These could be attributed to his sepsis and hypovolemia but could also be a sign of tension pneumothorax. Lung ultrasound was done which showed absence of lung sliding and presence of bar-code sign over right upper zone of lung.

A diagnosis of right tension pneumothorax was made combining all the clinical features and ultrasound findings. An emergency needle thoracocentensis was immediately done at right mid-clavicular line, second intercostal space which confirmed the diagnosis with presence of gush of air. Right chest tube was then inserted intra-operatively. Post-chest tube insertion, etCO2 level came down to $44 \mathrm{cmH} 2 \mathrm{O}$ initially but increased back to $59 \mathrm{cmH} 2 \mathrm{O}$. He also required low dose noradrenaline which was weaned off on day one post-operation. Postoperatively, patient was admitted to intensive care unit (ICU) for observation and weaning.

Upon arrival at ICU, it was noted there was no bubbling of underwater seal intercostal drain. Chest X-ray was done which showed ETT was far from carina, chest tube in-situ but right pneumothorax was still present. Second chest tube was inserted over right pleural space. Repeated chest X-ray showed expanded right lung.

In ICU, patient had persistent bronchospasm which resolved only four days later and chronic obstructive pulmonary disease (COPD) was suspected in view of patient being a chronic smoker. First chest tube was removed on day four postoperation. Patient was successfully extubated on day seven post-operation and second chest tube was removed one day after that. Patient was transferred to general surgical ward the following day and discharged well on day fifteen after surgery.

\section{DISCUSSION}

Pneumothorax is a well known but rare complication of GA. It can occur due to procedures around neck and chest wall including upper extremities block, subclavian or internal jugular vein central lines, surgery, positive pressure ventilation, over-pressure of airway, obstructed endotracheal tube and instrumentation of trachea or bronchi(1). In this patient, several contributory factors to pneumothorax were identified retrospectively.
He was a chronic smoker with possible COPD and had increased intra-abdominal pressure due to his primary pathology. Chronic smoker is reported to have higher risk of developing spontaneous pneumothorax in their lifetime possibly due to widespread inflammation of small airways $(2,3)$. Presence of COPD further increases the risk of pneumothorax especially with positive pressure ventilation even when small tidal volume is given(4). Barotrauma could also result from reduced lung and chest wall compliance secondary to increased intra-abdominal pressure(5).

Diagnosing pneumothorax in a patient under GA is challenging. Patients will not be able to complain of shortness of breath or chest pain, which are the usual presentation of pneumothorax. Moreover, access to chest intra-operatively is limited and mobile chest radiography as well as computed tomography (CT) scan was not feasible in our theatre setting.

In this case, the first sign detected was a persistent increase in end-tidal carbon dioxide level. Rise in end-tidal carbon dioxide is commonly due to inadequate minute ventilation, endobronchial intubation, bronchospasm and increased production of carbon dioxide for example in malignant hyperthermia(6). Therefore, it is logical to exclude common causes before suspecting pneumothorax.

Initial signs of pneumothorax could be subtle and variable. Reduced chest expansion and reduced air entry presented rather late in this patient. By then, it had developed into tension pneumothorax with the presence of tracheal deviation. There was no increased resonance of the lung involved and peak pressure was never high. Absence of desaturation could possibly be due to administration of $100 \%$ oxygen from beginning of surgery.

A bedside ultrasound which showed absence of sliding sign and presence of bar-code sign over involved lung increased the likelihood of diagnosis of pneumothorax(7). It has been shown that lung ultrasound is a safe, fast as well as effective tool in diagnosing pneumothorax and especially useful in operation room(7). Nevertheless, lung ultrasound requires the medical personnel to be trained in its usage and it does not replace clinical judgement in obvious case of pneumothorax. Furthermore, in our setting (a district hospital), ultrasound was not readily available in theatre or ICU. Once diagnosis of tension pneumothorax is made, there is no time to waste. In our case, needle thoracocentesis was done by anaesthetic team immediately. Pnemothorax was confirmed with rush of air and chest tube was then immediately inserted by surgeon in the same setting.

Diagnosing pneumothorax still poses difficulty in patients under general anaesthesia. In addition to classical clinical features of pneumothorax, persistent unexplained hypercapnia without desaturation should raise the suspicion of the diagnosis. Lung ultrasound provides rapid and accurate diagnosis of pneumothorax and anaesthesia providers should be well-versed with it as early intervention of pneumothorax is life-saving.

\section{Conflict of interest}

No conflict of interest was declared by the authors.

\section{REFERENCES}

1. Bacon AK, Paix AD, Williamson JA, Webb RK, Chapman MJ. Crisis management during anaesthesia: Pneumothorax. Qual Saf Health Care 2005; 14:18

2. Bense L, Eklund G, Wiman LG. Smoking and the increased risk of contracting pneumothorax. Chest 1987; 92:1009-12.

3. Cheng YL, Huang TW, Lin CK, Lee SC, Tzao C, Chen JC, et al. The impact of smoking in primary spontaneous pneumothorax. The Journal of Thoracic and Cardiovascular Surgery 2009; 138: 192-5

4. Fettal $\mathrm{N}$ and Taleb A. Pneumothorax secondary to chronic obstructive pulmonary disease. European Respiratory Journal 2012; 40: 558

5. Wauters J, Claus P, Brosens N, McLaughlin M, Hermans G, Malbrain M, et al. Relationship between Abdominal Pressure, Pulmonary Compliance, and Cardiac Preload in a Porcine Model. Critical Care Research and Practice 2012; 763181 6. Tautz TJ, Urwyler A, Antognini JF. Case Scenario: Increased end-tidal carbon dioxide; a diagnostic dilemma. Anesthesiology 2010; 112:440-6

7. Kline JP, Dionisio D, Sullivan K, Early T, Wolf J, Kline D. Detection of Pneumothorax with Ultrasound. AANA Journal 2013; 81: 265-71 